\title{
Reading enjoyment amongst non-leisure readers can affect achievement in secondary school
}

\section{Suzanne E. Mol* and Jelle Jolles}

Department of Educational Neuroscience and LEARN! Research Institute for Learning and Education, Faculty of Psychology and Education, VU University Amsterdam, Amsterdam, Netherlands

Edited by:

Carl Senior, Aston University, UK

Reviewed by:

Anna Julie Cunningham, Aston

University, UK

Julia Badger, University of Oxford, UK

*Correspondence:

Suzanne E. Mol, Department of

Educational Neuroscience, Faculty of Psychology and Education,

VU University Amsterdam, Van der

Boechorststraat 1, 1081 BT

Amsterdam, Netherlands

e-mail:s.e.mol@vu.nl
This study aimed to evaluate determinants of differences in leisure reading behavior and school achievement. We specifically examined reading enjoyment, mental imagery, and sex as predictors in a large, age-homogeneous sample of Dutch secondary school students $(N=1,071)$. Results showed that the prevalence of leisure reading was low in both the lower, pre-vocational track (19.5\%) and the higher, pre-academic track $(32.5 \%)$. Boys read even less than girls. Almost all leisure readers enjoyed reading and engaged in mental imagery, i.e., the propensity "to see images" of a written story in the mind's eye. Overall, boys who did not like to read for leisure had the poorest school performance. Non-leisure readers who reported that they enjoyed reading got higher school grades in the higher educational track. In the lower track, this was the case for girls. Our study findings imply that reading promotion programs should take into account individual differences in sex, achievement level, and reading enjoyment when aiming to decrease the academic achievement gap.

Keywords: leisure reading, reading enjoyment, mental imagery, sex differences, school achievement, early adolescence

\section{INTRODUCTION}

There is a large achievement gap between the secondary school students who do and those who do not read books during leisure time (OECD, 2010; Mol and Bus, 2011). From sixth grade onward (Jacobs et al., 2002) sex differences become salient as well in this respect, with boys reading less than girls (Coles and Hall, 2002; Logan and Johnston, 2009; Mullan, 2010). However, some of the non-leisure readers perform better than other non-leisure readers, and it is not known which factors are determinants of this variability. In order to develop effective programs to reduce achievement gaps in secondary school, it is imperative to gain insight into the determinants that could explain individual differences within groups that run a higher risk of lower school achievement. Non-leisure readers are such a group. The present paper describes a large-scale survey aimed at evaluating possible determinants and identifying which of these would be suitable for intervention programs.

We conducted our survey study in an age-homogeneous sample of seventh grade students $(N=1,071)$ from the Netherlands. These 12- and 13-year-olds had just made the transition from primary to secondary school. Adjusting to their new academic environment involves dealing with many challenges. The transition is accompanied by a major change in cognitive and social functioning; the school structure, and the nature of the curriculum is different, new subjects have to be learned, the social network changes, and new friends have to be made. Students have to learn to manage, plan, and execute various homework assignments competing for their attention. Consequently, students' leisure time activities change as well (e.g., Ferguson and Fraser, 1998; Pedersen, 2005). The demands of their new school environment may reduce the time that students have - and/or take - to read for leisure.

It has been found that almost fifty percent of Dutch 15-yearolds report that they never read for pleasure; this was even higher than the international average of $37 \%$ (OECD, 2010). It has to be taken into account, however, that while students might not read for leisure, this does not necessarily mean that they dislike reading books. Therefore, the current study aimed both to determine the prevalence of leisure reading in seventh grade as well as of the subjective "joy of reading" experienced by leisure versus non-leisure readers. Because of the recent indications that boys and girls may differ in neuropsychological development (e.g., Lenroot and Giedd, 2010) as well as in reading behavior and enjoyment (Coles and Hall, 2002; Jacobs et al., 2002; Chiu and McBride-Chang, 2006; Logan and Johnston, 2009; Mullan, 2010; OECD, 2010), we also investigated sex differences.

A recent meta-analysis showed that leisure readers in College and University graduated high school with higher GPAs than their non-leisure reading peers (Mol and Bus, 2011). A positive spiral of reciprocal causation seems to explain that leisure readers increase skills that are important for their academic success, such as their vocabulary and reading comprehension. Better skilled readers, in turn, are more likely to enjoy what they are reading, to continue reading voluntarily, and to increase their school performance. In general, students who enjoy reading can get absorbed by the narrative world when reading works of fiction (Green and Brock, 2002; Oatley, 2012). Such reading engagement is thought to support the construction of mental situational models that increase story comprehension (Mar, 2004; Oatley, 2011). Successful reading comprehension, in turn, is not only related to reading enjoyment, 
but also to academic success (Morgan and Fuchs, 2007; Retelsdorf et al., 2011). Therefore, for non-leisure readers in particular, it is important to determine whether their school achievement is or is not related to their general reading enjoyment. If that is the case, this could be a promising insight for interventions. To this end, we hypothesized that non-leisure readers who do enjoy reading get higher school grades than those who do not enjoy reading. We further expected our findings to indicate that girls in this subgroup achieve better than boys.

One ability that seems to affect reading enjoyment and reading comprehension is mental imagery or the propensity of readers to form mental pictures of the written story in "their mind's eye" (Sadoski and Paivio, 2001). Interestingly, mental imagery is considered to be an essential part of transportation into the narrative world (Green, 2004; Oatley, 2011). It is also thought to enhance reading comprehension, because forming vivid images of a story improves the quality of readers' mental situational models (Mar, 2004; Yarkoni et al., 2008; Speer et al., 2009; for a review, see De Koning and Van der Schoot, 2013). However, there is individual variability in the vividness with which people are able to picture scenes in "their mind's eye" (e.g., Cui et al., 2007). This variability seems to be related to experience (Isaac and Marks, 1994; Sadoski and Paivio, 2001; Gennari, 2012). As leisure readers are expected to have more experience with books and with building mental models that support story comprehension, we will examine whether they are more likely to engage in mental imagery than non-leisure readers. Until now, no sex differences have been reported in mental imagery (e.g., Richardson, 1995).

\section{THE CURRENT STUDY}

The reciprocal model of causation suggests that non-leisure readers are at highest risk of poor school achievement (Mol and Bus, 2011). Children who do not read books voluntarily are less likely to enjoy reading and engage less in mental imagery. Hence, this subgroup is most likely to receive relatively low school grades as compared to students who do read for pleasure and enjoy reading. In the Netherlands, this negative spiral could result in an overrepresentation of non-leisure readers in the lower general educational track of secondary school. That is, the Dutch school system is highly stratified from seventh grade onward. The lower, pre-vocational general educational track (i.e., VMBO) takes 4 years and allows students to continue with a vocational education. The higher, pre-academic educational track takes either five (i.e., HAVO) or six (i.e., VWO) years and prepares students for College and/or University. Students are assigned to one of these tracks in their final year of primary school, when they are 10- to 11years-old on average. Students' placement is based on their total score on a nationwide test that includes multiple-choice questions that measure students' aptitude in Dutch language, reading comprehension, math, world orientation (i.e., geography, biology, and history), and study skills (www.government.nl/issues/education). Research has indeed shown that students in the lower track read less frequently, have lower reading comprehension skills, and enjoy reading less than students in the higher track (Gille et al., 2010; The Dutch Inspectorate of Education, 2012). Lowertrack students often find reading texts for school boring and challenging, which is probably due to their relatively poor technical reading skills and lack of adequate comprehension strategies (Schram, 2007).

To better understand the consequences of non-leisure reading, it is important that researchers and practitioners acknowledge individual differences in adolescents' academic opportunities that are strongly related to their leisure reading habits from an early age onward. In non-stratified school systems, study findings may be confounded by achievement differences that can be attributed to students' leisure reading history, however. The Dutch schooling system, in contrast, offers us an opportunity to look into two groups that are ought to differ in school achievement, but whose within-group differences in schooling situation are relatively small. For example, students' grades reflect their performance on exams that are adjusted to their respective textbook knowledge, reading skills, and expected level of subject mastery. We expect that reading enjoyment and mental imagery will play a different role in the actual school achievement of students in the higher, pre-academic track as compared to students in the lower, prevocational track. That is, it may be particularly important that students enjoy reading in order to succeed in the higher track, because the complexity level of their courses and textbooks may require stronger developed reading abilities than needed in the lower track. Because girls generally are better students than boys (The Dutch Inspectorate of Education, 2012), it is hypothesized that boys who do not enjoy reading run the highest risk of low school performance in the higher track in particular. Importantly, our findings will apply to students attending different educational systems as well. This study could inform researchers and practitioners across the world about the role of reading enjoyment and mental imagery for students who are relatively low versus high achievers.

In sum, this study addressed the following research questions, separately for students in the lower and higher educational track of their first year in secondary school in the Netherlands:

(1) What is the occurrence of reading enjoyment and mental imagery among leisure and non-leisure readers?

(2) To what extent do reading enjoyment, mental imagery, and sex explain differences in the school achievement of non-leisure readers?

\section{MATERIALS AND METHODS PARTICIPANTS}

A large, homogeneous group of 1,071 seventh graders from five secondary schools in the Netherlands (548 boys, 523 girls), with a mean age of $M=12.54$ years $(\mathrm{SD}=0.53$; Range: $11.25-$ 14.75 years) was analyzed. All but 19 students were 12 years old $(47.5 \%)$ and 13 years old $(50.7 \%)$. Except for students who repeated or skipped a year in kindergarten $(n=39)$, students who had repeated $(n=126)$ or skipped $(n=32)$ a grade in primary or secondary school (i.e., grade 1 to grade 7 ) have been excluded from this sample in order to make our group homogeneous with respect to both age and developmental level. Almost all participants had the Dutch nationality $(96.7 \%)$ and were native speakers $(95.8 \%)$. Some students $(14.7 \%)$ had one or two immigrant parents, of whom $59.0 \%$ came from western countries. Thirty-four 
children $\left(3.2 \% ; n_{12 \text {-year-olds }}=14, n_{13 \text {-year-olds }}=20\right)$ self-reported that they were officially diagnosed with dyslexia.

Participants were in their first year of secondary school. The schools they attended offered the lower and the higher educational tracks in both single-track classrooms (i.e., lower = VMBO; higher = HAVO, and VWO), as well as in combined track classrooms (i.e., lower $=\mathrm{VMBO} / \mathrm{HAVO}$; higher $=\mathrm{HAVO} / \mathrm{VWO})$. In the latter, combined classroom type, students stream into a single track classroom in grade 8 or 9. Overall, $35 \%$ of our participants $(n=375$; $50.1 \%$ boys) were in the lower general educational track, which closely resembles the Dutch national average of $40 \%$ (Ministry of Education Culture and Science, 2011). In our study, $65 \%$ of the participants ( $n=696 ; 51.7 \%$ boys) were enrolled in the higher educational track.

\section{MEASURES}

\section{Leisure reading}

Students were asked to select those activities they engaged in during leisure time. They were presented with a list of ten activities, including reading. The other activities could be categorized into: physical activities (sports, playing outside, acting); social activities (calling friends, online chatting); creative activities (doing arts and crafts, painting); and screen-related activities (playing video games, using the computer and Internet). For the current study, we categorized all students who checked reading as a leisure activity as leisure readers $(n=299)$, and those who did not select reading as non-leisure readers $(n=772)$.

\section{Reading enjoyment}

Students were asked to respond to the following statement: "I love to read books (fiction, comic books)" on a 3-point scale. In reading research (e.g., Bennett et al., 2002; Coles and Hall, 2002; Acevedo-Polakovich et al., 2007), a single-item is often used to tap into this construct. In the field of psychology (e.g., Wanous et al., 1997; Gardner et al., 1998; Dollinger and Malmquist, 2009), it has been shown that such an assessment method is also valid and reliable, particularly in large samples. We dichotomized all answers to create a group of non-enjoyers (i.e., not at all true), and reading enjoyers (i.e., somewhat true, completely true). We decided to combine the latter answer options, because preliminary analyses showed that our findings were comparable for the group who agreed "somewhat" and "completely."

\section{Mental imagery}

Students were asked to indicate whether they recognized themselves in the following profile: "While I am reading a story, I use my imagination. I see a film of the story in my mind's eye, and I see what happens, and what the main character looks like." This single-item measure has been shown to be a valid estimator of imagery. In a study among 124 lower-track students attending grade 7-9 and 110 of their parents (Mol et al., unpublished data), we found strong correlations with the sum score of ten items of a validated Dutch questionnaire capturing visual, auditory, and social imagery during reading (Tellegen and Frankhuisen, 2002) and our single-item measure: $r_{\text {adolescents }}=0.57(p<0.001)$ and $r_{\text {parents }}=0.65(p<0.001)$.
Students who responded "not at all" in this study were assigned to the non-imagery group; whereas students who selected "somewhat true" or "completely true" were categorized as mental imagery users.

\section{School achievement}

Final grades (ranging from $1.0=$ very bad, to $10.0=$ outstanding) for the first semester of the three school subjects "Dutch," "mathematics," and "English as a foreign language" were requested for each student. These grades were used to judge school success (Reed et al., 2010), since successful performance in these three subjects is a main goal of Dutch secondary education (Ministry of Education, Culture and Science, 2006). To ensure that the distribution of scores was similar for each school, and to control for possible grading differences across schools, we first standardized children's average grade within each school. The overall standardized mean school achievement was equal to $M=0$ and $\mathrm{SD}=1$ (range: -3.50 to 2.87 ).

Mean grades significantly differed between classroom types (e.g., $\mathrm{HAVO}=$ single-track classroom, $\mathrm{HAVO} / \mathrm{VWO}=$ combinedtrack classroom). Students attending single-track classrooms received significantly higher mean school grades in both the lower $(n=136, M=0.26, \mathrm{SD}=0.89)$ and higher general educational tracks $(n=330, M=0.27, \mathrm{SD}=1.02)$ than students attending combined classrooms in both tracks ( $n_{\text {lower track }}=224$, $\left.M=-0.41, \mathrm{SD}=0.92 ; n_{\text {higher track }}=256, M=-0.13, \mathrm{SD}=0.94\right)$. A plausible explanation could be that teachers have to be relatively stricter when assigning good grades to students in combined classrooms, because students' referral to a single-track classroom with a relatively higher (e.g., VWO) or lower level (e.g., HAVO) at the end of grade 7 or 8 is based on their mean grades. Consequently, we controlled for classroom type in each analysis with school achievement.

\section{Demographics}

Students reported their sex (boy/girl), birth date, age, educational track, and classroom type in secondary school (VMBO, VMBO/HAVO, HAVO, HAVO/VWO, VWO). They also reported whether they had skipped or repeated a grade in primary or secondary school. They further filled in their own country of birth as well as their parents', their first language, and whether they were officially diagnosed with dyslexia.

\section{PROCEDURE}

This study was part of the LEERLIJN study, for which ten schools across the Netherlands were recruited. Care was taken to draw the schools from the pool of "mainstream" secondary schools in the Netherlands. In this process, we aimed to ensure that the schools were similar with respect to socio-demographic factors, ethnicity, and educational quality. For the current comparison study, we excluded four schools that only offered the higher educational track, and one school that had classrooms with a heterogeneous combination of all tracks. Consequently, any differences between students from the lower and higher tracks cannot be attributed to differences in school community, because all children attended secondary schools that offered both lower and higher educational tracks. 
In their second semester, students individually completed an online survey on a school computer in a classroom setting. A research assistant explained how to access and fill in the survey. Together with the classroom teacher, the assistant made sure that students worked quietly and independently. Response rates were high: Across the five included schools, complete data were collected for $84.2 \%(n=1,228)$ of all students who received an informational letter and got parental consent to participate. Teachers' response rates for providing students' average school grades was $88.1 \%(n=944)$. The online questionnaire format did not allow students to leave any question unanswered, so there were no missing values.

\section{RESULTS}

As is shown in Table 1, students from the two general educational tracks differed on all our variables of interest (i.e., leisure reading, reading enjoyment, mental imagery, school achievement). No differences were found on any background variable (i.e., age, sex, ethnicity, first language, dyslexia diagnosis). In the following sections, we will answer our research questions separately for the lower versus higher educational tracks. First, we will look into frequency distributions. Second, within the subgroup of non-leisure readers, we examined the determinants of students' school achievement by conducting a GLM Univariate ANCOVA, in which we entered reading enjoyment, imagery, and sex as the independent variables, and classroom type as a covariate.

\section{LOWER EDUCATIONAL TRACK}

\section{Leisure reading differences}

In the lower educational track, 375 seventh graders participated. Only $19.5 \%(n=73)$ of students indicated that they read during leisure time. Sixty-six percent of all students were reading enjoyers and $88 \%$ engaged in mental imagery.

As expected, leisure readers reported significantly more reading enjoyment $\left[\chi^{2}(1)=35.84, p<0.001\right]$ and mental imagery $\left[\chi^{2}(1)=7.36, p=0.007\right]$ than non-leisure readers. Specifically, almost all non-enjoyers were non-leisure readers (97.6\%; $\mathrm{SR}=2.1)$. There was hardly any student who did not engage in mental imagery and yet was a leisure reader $(0.04 \%$; $S R=-2.3)$. In short, leisure readers were very likely to enjoy reading and to engage in mental imagery.

A minority of $12 \%$ of all boys and $27 \%$ of all girls indicated that they read during their leisure time. Significant sex differences were found in leisure reading $\left[\chi^{2}(1)=14.50, p<0.001\right]$ : only $30.1 \%$ of all leisure readers were boys $(\mathrm{SR}=-2.4)$. In addition, more boys did not enjoy reading $(\mathrm{SR}=2.0)$ than girls $(\mathrm{SR}=-2.1)$, $\chi^{2}(1)=12.70, p<0.001$ (see Table 2 for frequency distributions). There were no sex differences in mental imagery $\left[\chi^{2}(1)=0.60\right.$, $p=0.438]$.

\section{School achievement differences among non-leisure readers}

In the next analysis, we only included non-leisure readers $(n=302)$. As is shown in Table 3, almost all non-leisure readers who enjoyed reading engaged in mental imagery $(\mathrm{SR}=3.4)$, whereas non-leisure readers who did not enjoy reading were significantly more likely not to engage in mental imagery $(\mathrm{SR}=-2.8)$, $\chi^{2}(1)=23.06, p<0.001$.

We conducted a GLM Univariate ANCOVA with school achievement as the dependent variable, and tested main effects of reading enjoyment, mental imagery, and sex as well as the interactions between sex and reading enjoyment, and sex and imagery. Mean grades were available for 290 students. The overall model with these two interaction terms explained $16.8 \%$ of the variance

Table 1 | Distribution of seventh graders over lower versus higher educational tracks in secondary school.

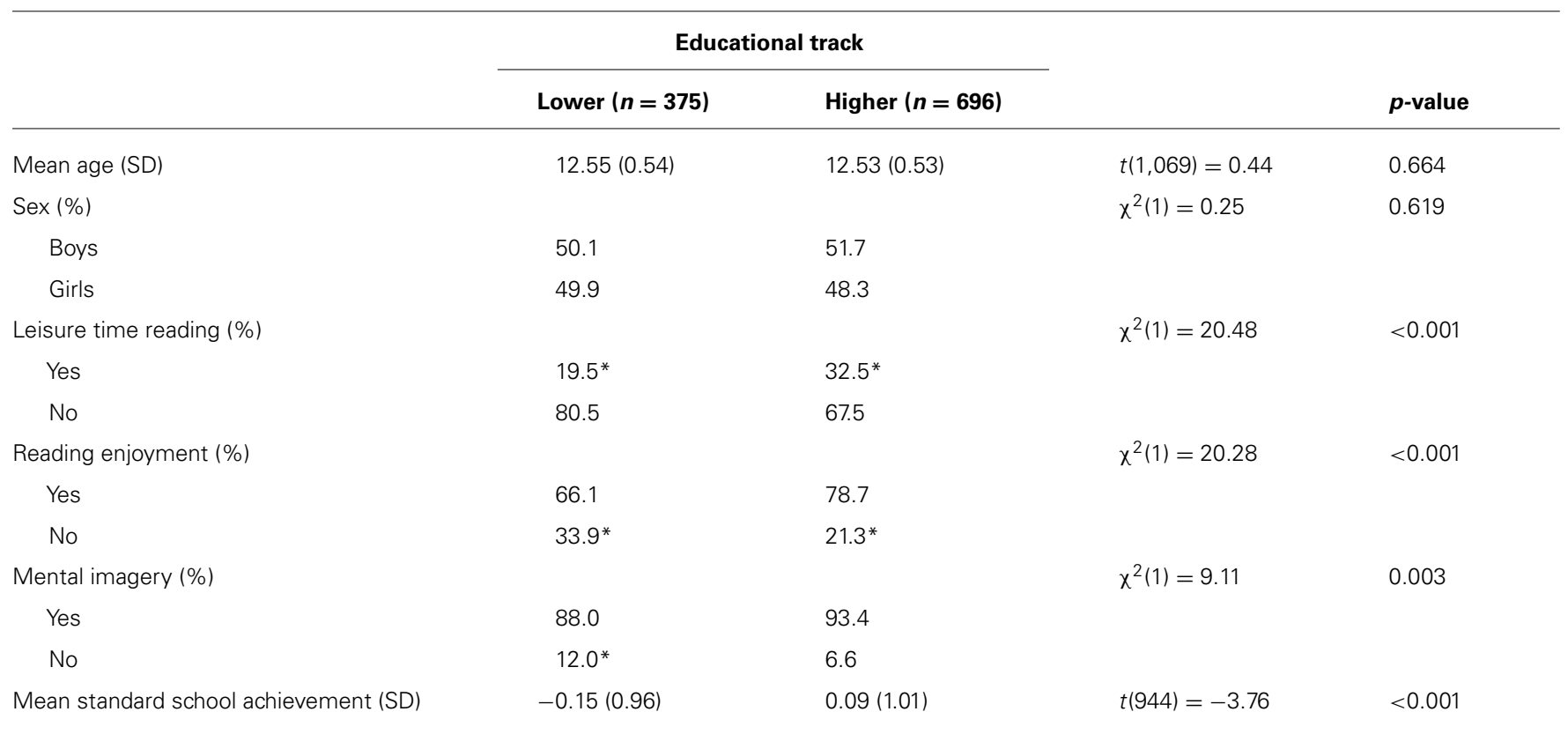

\footnotetext{
* $-2<$ standardized residuals $>2$
} 
Table 2 | Sex distribution between general educational tracks when comparing leisure time readers with non-leisure readers on reading enjoyment and mental imagery.

\begin{tabular}{|c|c|c|c|c|c|c|c|c|c|c|}
\hline \multirow{3}{*}{$\begin{array}{l}\text { Educational } \\
\text { track }\end{array}$} & \multirow{3}{*}{ Sex } & \multirow{3}{*}{$\begin{array}{l}\text { Leisure } \\
\text { reader }\end{array}$} & \multicolumn{4}{|c|}{ Reading enjoyment } & \multicolumn{4}{|c|}{ Mental imagery } \\
\hline & & & \multicolumn{2}{|c|}{ No } & \multicolumn{2}{|c|}{ Yes } & \multicolumn{2}{|c|}{ No } & \multicolumn{2}{|c|}{ Yes } \\
\hline & & & $n$ & $\%$ & $n$ & $\%$ & $n$ & $\%$ & $n$ & $\%$ \\
\hline \multirow[t]{4}{*}{ Lower } & Boys & Yes & 2 & 9.1 & 20 & 90.9 & 1 & 4.5 & 21 & 95.5 \\
\hline & & No & 78 & 47.0 & 88 & 53.0 & 24 & 14.3 & 142 & 85.5 \\
\hline & Girls & Yes & 1 & 2.0 & 50 & 98.0 & 1 & 2.0 & 50 & 98.0 \\
\hline & & No & 46 & 33.8 & 90 & 66.2 & 19 & 14.0 & 117 & 86.0 \\
\hline \multirow[t]{4}{*}{ Higher } & Boys & Yes & 2 & 2.9 & 68 & 97.1 & 3 & 4.3 & 67 & 95.7 \\
\hline & & No & 108 & 37.2 & 182 & 62.8 & 29 & 10.0 & 261 & 90.0 \\
\hline & Girls & Yes & 0 & .0 & 156 & 100.0 & 2 & 1.3 & 154 & 98.7 \\
\hline & & No & 38 & 21.1 & 142 & 78.9 & 12 & 6.7 & 168 & 93.3 \\
\hline
\end{tabular}

Table 3 | Differences in reading enjoyment and mental imagery for non-leisure readers in lower and higher general educational tracks.

\begin{tabular}{|c|c|c|c|c|c|c|}
\hline \multirow{3}{*}{$\begin{array}{l}\text { Educational } \\
\text { track }\end{array}$} & \multirow{3}{*}{ Sex } & \multirow{3}{*}{$\begin{array}{l}\text { Reading } \\
\text { enjoyment }\end{array}$} & \multicolumn{4}{|c|}{ Mental imagery } \\
\hline & & & \multicolumn{2}{|c|}{ No } & \multicolumn{2}{|c|}{ Yes } \\
\hline & & & $n$ & $\%$ & $n$ & $\%$ \\
\hline \multirow[t]{6}{*}{ Lower } & Boys & No & 18 & 23.1 & 60 & 76.9 \\
\hline & & Yes & 6 & 6.8 & 82 & 93.2 \\
\hline & Girls & No & 14 & 30.4 & 32 & 69.6 \\
\hline & & Yes & 5 & 5.6 & 85 & 94.4 \\
\hline & Total & No & 32 & 25.8 & 92 & 74.2 \\
\hline & & Yes & 11 & 6.2 & 167 & 93.8 \\
\hline \multirow[t]{6}{*}{ Higher } & Boys & No & 15 & 13.9 & 93 & 86.1 \\
\hline & & Yes & 14 & 7.7 & 168 & 92.3 \\
\hline & Girls & No & 7 & 18.4 & 31 & 81.6 \\
\hline & & Yes & 5 & 3.5 & 137 & 96.5 \\
\hline & Total & No & 22 & 15.1 & 124 & 84.9 \\
\hline & & Yes & 19 & 5.9 & 305 & 94.1 \\
\hline
\end{tabular}

$\left[F(6,283)=10.74, p<0.001, \eta^{2}=0.19\right)$. The main effects for sex $\left[F(1,283)=3.97, p=0.053, \eta^{2}=0.01\right]$, reading enjoyment $\left[F(1,283)=1.41, p=0.235, \eta^{2}=0.00\right]$, and mental imagery $\left[F(1,283)=0.53, p=0.467, \eta^{2}=0.00\right)$ were not significant. The covariate classroom type was $[F(1,283)=42.60, p<0.001$, $\left.\eta^{2}=0.13\right]$. The interaction between sex and reading enjoyment was significant as well $\left[F(1,283)=6.41, p=0.012, \eta^{2}=0.02\right]$. As is shown in Figure 1A, girls who were reading enjoyers scored 0.40 average grade points higher than girls who were non-enjoyers; whereas boys' reading enjoyment did not seem to explain their school achievements. In short, reading enjoyment appears to play a role in the school achievement of girls in particular.

\section{HIGHER EDUCATIONAL TRACK Leisure reading differences}

Self-report data were collected for 696 students in the higher educational track. A minority of $32.5 \%(n=226)$ of seventh graders indicated that they read during their leisure time. About $80 \%$ enjoyed reading and $93.4 \%$ engaged in mental imagery (see Table 1).

Leisure readers were significantly more likely to enjoy reading $\left[\chi^{2}(1)=83.02, p<0.001\right]$ and to engage in mental imagery $\left[\chi^{2}(1)=10.48, p=0.001\right]$ than non-leisure readers. Specifically, the majority of non-enjoyers were categorized as non-leisure readers $(98.6 \%$; $S R=4.6)$. In addition, the subset of students who did not engage in mental imagery $(n=46)$ were hardly categorized as leisure readers $(0.02 \%$; $S R=-2.6)$. Put differently, most leisure readers enjoyed reading and engaged in mental imagery.

Nineteen percent of all boys and $46 \%$ of all girls were leisure readers. Of all leisure readers, $31.0 \%$ were boys. Significant sex differences were found in leisure reading $\left[\chi^{2}(1)=57.71\right.$, $p<0.001)$ and reading enjoyment $\left[\chi^{2}(1)=38.45, p<0.001\right]$ : Boys were underrepresented as leisure readers $(S R=-4.3)$ and reading enjoyers ( $\mathrm{SR}=-2.0$ ), but more likely to be categorized as non-leisure readers $(\mathrm{SR}=3.0)$ and non-enjoyers $(\mathrm{SR}=3.8)$. The opposite pattern was found for girls $\left(\mathrm{SR}_{\text {leisure readers }}=4.5\right.$, $\mathrm{SR}_{\text {enjoyers }}=2.1 ; \mathrm{SR}_{\text {non-leisure readers }}=-3.1, \mathrm{SR}_{\text {non-enjoyers }}=-4.0$, respectively). This implies that more girls than boys were leisure readers and reading enjoyers (see Table 2 ). Finally, the standardized residuals did not exceed the critical range for mental imagery [i.e., were $-1.7,1.7 ; \chi^{2}(1)=6.28, p=0.012$ ], showing no sex differences.

\section{School achievement differences among non-leisure readers}

Most non-leisure readers $(n=470)$ enjoyed reading $(68.9 \%)$ and engaged in mental imagery $(91.3 \%)$. Those who did not engage in mental imagery were most likely to be categorized as non-enjoyers of reading $(\mathrm{SR}=2.6), \chi^{2}(1)=10.71, p=0.001$ (see Table 3 ).

Mean school grades were available for 400 non-leisure readers in the higher track. GLM Univariate ANCOVA analyses 


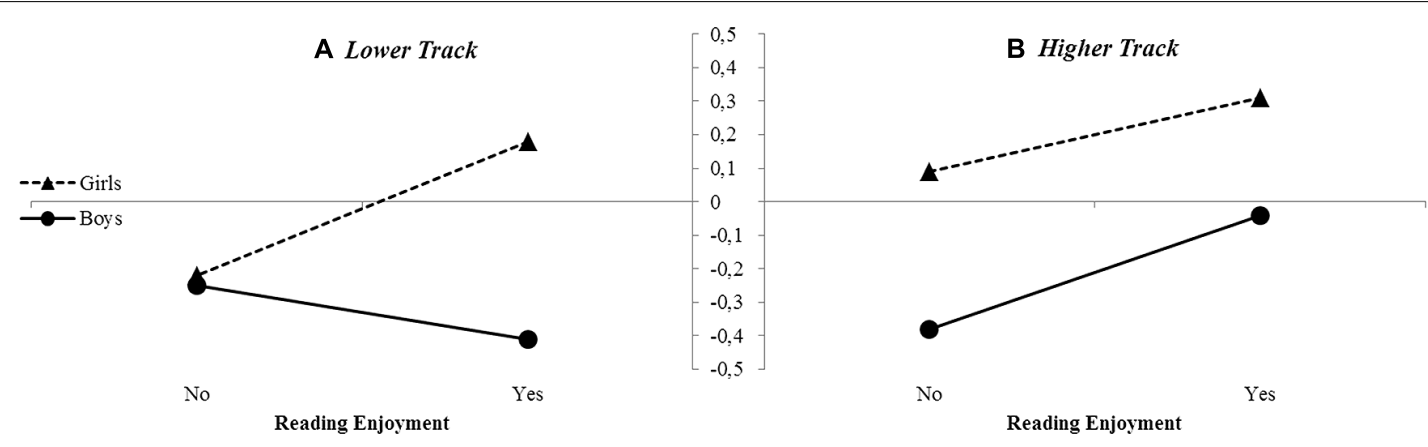

FIGURE 1 | School achievement differences explained by sex and reading enjoyment in non-leisure readers, for the lower (A) and higher (B) general educational tracks.

showed that sex, reading enjoyment, mental imagery, and classroom type explained $7.8 \%$ of the variance of school achievement $\left[F(6,393)=6.44, p<0.001, \eta^{2}=0.09\right]$. The interaction between sex and reading enjoyment was not significant $\left[F(1,393)=0.01, p=0.938, \eta^{2}=0.00\right]$. Further, the interaction between sex and mental imagery only approached significance $\left[F(1,393)=3.48, p=0.059, \eta^{2}=0.01\right]$ and will not be explored further due to the relatively small percentage $(n=31)$ of students who did not engage in mental imagery.

Main effects were found for sex $[F(1,393)=13.40$, $\left.p<0.001, \eta^{2}=0.03\right]$ and reading enjoyment $[F(1,393)=4.92$, $\left.p=0.027, \eta^{2}=0.01\right]$ and the covariate classroom type $\left[F(1,393)=8.75, p=0.003, \eta^{2}=0.02\right]$, but not for mental imagery $\left[F(1,393)=0.07, p=0.791, \eta^{2}=0.00\right]$. Girls who were reading enjoyers scored 0.22 standardized, average grade points higher than girls who were non-enjoyers; and boys who were reading enjoyers scored 0.34 grade points higher than boys who were non-enjoyers (see Figure 1B). Overall, analyses showed that reading enjoyment played a positive role in the school achievement scores of both boys and girls.

\section{DISCUSSION}

This study offered the unique opportunity to examine which determinants of leisure reading are related to school achievement in a large number of students who were similar in educational stage. This similarity reduced variability related to age and schooling. Two research questions were addressed for both the 375 students in the lower track and the 696 students in the higher track of the participating Dutch schools. First, we found that a minority of only $19.5 \%$ of students in the lower and $32.5 \%$ in the higher educational track indicated that they read during their leisure time. Almost all these leisure readers enjoyed reading and formed images of the story they were reading in "the mind's eye" (i.e., they engaged in mental imagery). As expected, more girls than boys read outside school and enjoyed reading, whereas no sex differences were found for mental imagery. Second, the majority of non-leisure readers reported that they enjoyed reading. Except for boys in the lower track, this subgroup of reading enjoyers performed better academically than those who did not enjoy reading.
Secondary school students are not a homogeneous group in terms of school achievement and leisure reading behavior. The advantage of a highly stratified educational system like the one in the Netherlands is that we can remove some heterogeneity by separately examining relatively low and high achievers attending the lower and higher educational tracks, respectively. In this study, we found that a greater percentage of students in the lower track were non-leisure readers, did not enjoy reading, and did not engage in mental imagery compared to students in the higher tracks. Lowertrack students also got lower school grades on average. These findings highlight the importance of looking into subgroups of secondary school students when aiming to understand the relation between leisure reading and school achievement; a relation that is affected by adolescents' reading history as well as the quality of their home literacy environment from an early age onward (Conlon et al., 2006). Such an approach can inform interventions that focus on students who run the highest risk of poor school achievement within relatively lower- and higher-achieving groups.

The first aim of this study was to examine the occurrence of leisure reading, reading enjoyment, and mental imagery of 12and 13-year-old Dutch secondary school students. We found that the majority of students in both educational tracks did not list reading among their leisure activities. More specifically, eight out of ten lower-track students and two out of three higher-track students did not engage in leisure reading. We investigated reading as an integral part of students' leisure time activities instead of using a question format that is likely to elicit more socially desirable answers, such as estimating reading frequencies (Mol and Bus, 2011). Our approach seemed to reveal an even more skewed distribution of adolescent readers than was found in the recent PISA-investigation, in which $49 \%$ of Dutch fifteen-year-old students indicated that they never read for pleasure (Gille et al., 2010; OECD, 2010). Interestingly, more than half of the non-leisure readers in our sample were willing to admit that they enjoyed reading books and comics in general.

Non-leisure readers who did not enjoy reading hardly used mental imagery strategies during reading; whereas those who did read for leisure were almost all imagery users. In both educational tracks, about $94 \%$ of the non-leisure readers who indicated that they enjoy reading in general also engaged in mental imagery. 
These findings seem to be in line with previous research linking reading habits, mental imagery, and reading enjoyment, as part of the experience of transportation into the narrative world (e.g., Green, 2004; Busselle and Bilandzic, 2008; Oatley, 2011; Weibel et al., 2011). In addition, recent theories of embodied cognition (Barsalou, 2008; Glenberg, 2011) propose that reading about a situation in a novel or a story drives the brain into perceptual, active, and emotional states that simulate the mental states that arise during the perception of, and the acting in, an exact same real-life situation. For example, neuroscientific studies show that direct speech statements in a story activate the auditory cortex (Yao et al., 2011), and that reading about happy events elicits greater activity in the muscles that control smiling (Havas et al., 2010). Reading a sentence that implies fictive motion (e.g., The road runs along the coast) produces corresponding simulations of motion through space in the brain (Matlock, 2004). Such simulation is thought to make reading an enjoyable experience (Oatley, 1999; Mar and Oatley, 2008). Future studies should examine whether mental imagery or its vividness is a prerequisite for, or a consequence of, reading enjoyment, or whether these two aspects are reciprocally related. It may further be interesting to examine the role of mental imagery across various school topics (e.g., math, science), as well as across media. Recent studies with adults show that high levels of vividness may enhance the enjoyment of reading books but not of watching movies (e.g., Green et al., 2008; Weibel et al., 2011), but it is not yet known whether this applies equally to early adolescents.

It could seem discouraging that students who just made the transition to secondary school are not very likely to read outside school. However, it is promising that plenty of non-leisure readers in our study did admit that they enjoy reading in general. Fiftynine percent of these students in the lower educational track and $69 \%$ in the higher track claimed to enjoy reading. In this subgroup of non-leisure readers, therefore, it may not be fruitful to stimulate leisure reading through aiming to affect their "subjective joy of reading." This seems to be in line with models that link actual behavior with motivation (for reviews see, for example, Conner and Armitage, 1998; Eccles and Wigfield, 2002), also within the domain of reading (e.g., Guthrie et al., 2012; Schiefele et al., 2012). One explanation for our current finding could be that students' transition to secondary school has changed the way they spend their leisure time so that they stopped reading voluntarily. In future research, it would be interesting to explore whether children think that they read less or more than they did in primary school and if so, whether they could explain why this is the case. Students' school transition does not necessarily have to change their enjoyment of reading books yet, however. According to the negative spiral of reading behavior, it can be speculated that this subgroup of non-leisure readers will lose their current reading enjoyment over the course of their secondary school career; their lack of reading practice may result in less reading enjoyment and decreasing school grades. As long as children admit to enjoying reading in general, it may be particularly important, therefore, that they learn how to effectively structure their time outside school. Early adolescents may particularly need assistance with creating enjoyable reading opportunities, as they are known to be undergoing profound changes in neuropsychological and brain development (e.g., Shaw et al., 2006; Giedd, 2008; Crone and Dahl, 2012). Research shows that parents are still important role models, who can actively guide their early adolescents in their activities or who can help them select materials that match their interests and reading level (Love and Hamston, 2004; Klauda, 2009).

The second aim of this study was to look into the role of sex, reading enjoyment, and mental imagery in the school achievement of non-leisure readers. In the higher track, boys and girls who did not enjoy reading got significantly lower grades than their same-sex peers who did enjoy reading. This also was the case for girls in the lower track. For these boys and girls, it may be interesting to examine whether their school achievement will improve after enhancing their reading enjoyment. Experimental studies in classroom settings are yet limited, but there is some evidence in lower grade levels that programs including a motivational aspect improve students' reading engagement (e.g., Souvignier and Mokhlesgerami, 2006; Guthrie et al., 2007; DeNaeghel etal., 2013). For example, instructional practices that focus on the relevance of a text, students' own choice, reading success, collaborative structures, and thematic units seem to increase important motivational processes as intrinsic motivation, perceived autonomy, self-efficacy, social motivation, and mastery goals, respectively (Guthrie et al., 2007). Another approach would be to teach mental imagery strategies, which may affect students' reading comprehension (Hibbing and RankinErickson, 2003; Algozzine and Douville, 2004; for a review, see De Koning and Van der Schoot, 2013). In line with previous research (Green and Brock, 2002; Oatley, 2012), our study suggests that such an intervention may also benefit students' reading enjoyment. The positive spiral of reading behavior implies that improving the reading enjoyment in this subgroup of nonenjoyers could enhance their leisure reading behavior and, hence, their school achievement.

Our study highlights that boys are in particular need of successful reading interventions. Almost nine out of ten boys in the lower educational track and eight out of 10 boys in the higher educational track were categorized as non-leisure readers. Interestingly, the sex distribution of reading enjoyers in our sample was rather equal among non-leisure readers: about half of the non-leisure readers who enjoyed reading were boys, in both the lower (49\%) and higher (56\%) educational tracks. The book market already seems to have developed ways to address the fact that boys may need more stimulation than girls to engage in reading activities. For example, numerous websites can be found online that list books that are considered of specific interest for boys, by classifying them on a range of topics (e.g., animals, war, robots, outer space, sports) or genres (e.g., science fiction, fantasy, young adult) that boys are thought to be attracted to. Some studies suggest that parents and teachers should be encouraged to develop a broader perspective on the range of (online) texts that they would count as "appropriate reading materials" in order for boys to start reading (Telford, 1999; Love and Hamston, 2004). It should be examined, however, whether reading texts in newspapers, magazines, blogs, and/or on informative websites could equally impact students' reading enjoyment, mental imagery, and reading achievement as reading works of fiction (e.g., Oatley, 1999; Mar et al., 2006). Students seem to 
particularly be engaged in their reading activity when they are absorbed in the world of the book. The positive spiral of reading suggests that such absorption is needed to continue reading voluntarily.

Our study further provides insight in the group that run the highest risk of poor school performance. Unexpectedly, the reading enjoyment of male non-leisure readers in the lower track was not related to their school achievement. Boys who claimed to enjoy reading got comparable grades as boys and girls who did not enjoy reading. It could be that their reading abilities are so relatively poor that their general reading enjoyment cannot function as a protective factor for low school grades. The current reading abilities of these low achievers may not be sufficient for understanding the age-appropriate reading materials that are supposed to be fun for them to read voluntarily. Books that match their reading level are often written for younger children (Schram, 2007). Either reading promotion initiative is likely to result in a further avoidance of leisure reading, which will further increase their risk of dropping out of secondary or tertiary education. It may be necessary to first train these students' (technical) reading skills. Put differently, we expect that students need a minimum level of reading abilities before their school achievement will be affected by their general reading enjoyment. Future studies should reveal whether this indeed is the case.

We found no direct relation between mental imagery and school achievement. This finding should be interpreted with caution, however, due to the ceiling effect that seemed to affect our mental imagery measure. To replicate and extend our findings, a questionnaire should be used that captures more variability and modalities in mental imagery behavior (see, for example, Blajenkova et al., 2006). Furthermore, our current indicator of reading enjoyment may have resulted in a dichotomous split that neglected the nuance of the group of students who do not really hate books but who also do not enjoy them as much as their peers who really love reading. Future studies that embed reading enjoyment into the broader concepts of reading motivation, attitude, and interest may reveal a more comprehensive picture as well (Conradi et al., 2014). In addition, we looked at students' average school grades instead of their reading abilities. Stronger relations could be expected if we had measured students' actual reading performance. Because reading abilities are an important indicator of general academic success (e.g., Alexander et al., 2007), it is plausible that students with higher grades in our sample also are the better readers. Due to the correlational nature of our study, however, we cannot be sure whether those who did not enjoy reading are the low-achieving students, or whether the low achievers particularly are low reading enjoyers. Learning more about the development of low school achievement, low reading enjoyment and their interaction from an early age onward may particularly be useful when identifying the best approach for reaching students with reading stimulation programs. Interestingly, a peer culture of reading encouragement in schools seems to enhance the reading achievement of both boys and girls, regardless of their reading proficiency (Chiu and McBride-Chang, 2006).

In summary, our study indicates that we have to keep in mind that adolescents' behaviors may not reflect their motivation and emotional responses toward reading. That is, we identified a group of seventh grade students who enjoy reading even when reading is not among their preferred leisure activities. Accordingly, the present data imply that reading enjoyment could make a difference in students' school careers. Indeed, we showed that girls who were non-leisure readers and enjoyed reading in general got higher average school grades in both educational tracks. Boys who enjoyed reading in the higher educational track also excelled compared to boys who did not enjoy reading. For their classmates who do not enjoy reading, it could be expected that their school achievement benefits from higher reading enjoyment levels. Boys in the lower track, however, are not likely to profit from such an intervention. This study, therefore, underscores the importance of acknowledging individual differences in sex and reading enjoyment when aiming to improve the academic careers of higher versus lower achieving students.

\section{ACKNOWLEDGMENTS}

The LEERLIJN study is conducted by the Center for Brain and Education, which is part of the LEARN! Research Institute of the VU University Amsterdam. The LEERLIJN study was made possible by financial support from the Netherlands Organization for Scientific Research (FES-NWO grant/project number: 05632-011). The authors gratefully acknowledge the contribution of participating pupils and their teachers. In addition, we thank Wietske Idema, Karin Vander Heyden, Anneleen Post, and Marije Broens for their substantial contribution to the collection of data.

\section{REFERENCES}

Acevedo-Polakovich, I. D., Lorch, E. P., and Milich, R. (2007). Comparing television use and reading in children with ADHD and non-referred children across two age groups. Media Psychol. 9, 447-472. doi: 10.1080/1521326070 1291387

Alexander, K. L., Entwisle, D. R., and Olson, L. S. (2007). Lasting consequences of the summer learning gap. Am. Sociol. Rev. 72, 167-180. doi: $10.1177 / 000312240707200202$

Algozzine, B., and Douville, P. (2004). Use mental imagery across the curriculum. Prev. Sch. Fail. 49, 36-39. doi: 10.3200/PSFL.49.1.36

Barsalou, L. W. (2008). Grounded cognition. Annu. Rev. Psychol. 59, 617-645. doi: 10.1146/annurev.psych.59.103006.093639

Bennett, K. K., Weigel, D. J., and Martin, S. S. (2002). Children's acquisition of early literacy skills: examining family contributions. Early Child. Res. Q. 17, 295-317. doi: 10.1016/S0885-2006(02)00166-7

Blajenkova, O., Kozhevnikov, M., and Motes, M. A. (2006). Object-spatial imagery: a new self-report imagery questionnaire. Appl. Cogn. Psychol. 20, 239-263. doi: 10.1002/acp. 1182

Busselle, R., and Bilandzic, H. (2008). Fictionality and perceived realism in experiencing stories: a model of narrative comprehension and engagement. Commun. Theory 18, 255-280. doi: 10.1111/j.1468-2885.2008.0 0322.x

Chiu, M. M., and McBride-Chang, C. (2006). Gender, context, and reading: a comparison of students in 43 countries. Sci. Stud. Read. 10, 331-362. doi: $10.1207 / \mathrm{s} 1532799 x s s r 1004 \_1$

Coles, M., and Hall, C. (2002). Gendered readings: learning from children's reading choices. J. Res. Read. 25, 96-108. doi: 10.1111/1467-9817.00161

Conlon, E. G., Zimmer-Gembeck, M. J., Creed, P. A., and Tucker, M. (2006). Family history, self-perceptions, attitudes and cognitive abilities are associated with early adolescent reading skills. J. Res. Read. 29, 11-32. doi: 10.1111/j.1467-9817.2006.00290.x

Conner, M., and Armitage, C. J. (1998). Extending the theory of planned behavior: a review and avenues for further research. J. Appl. Soc. Psychol. 28, 1429-1464. doi: 10.1111/j.1559-1816.1998.tb01685.x 
Conradi, K., Jang, B. G., and McKenna, M. C. (2014). Motivation terminology in reading research: a conceptual review. Educ. Psychol. Rev. 26, 127-164. doi: $10.1007 / \mathrm{s} 10648-013-9245-\mathrm{z}$

Crone, E. A., and Dahl, R. E. (2012). Understanding adolescence as a period of social-affective engagement and goal flexibility. Nat. Rev. Neurosci. 13, 636-650. doi: $10.1038 / \mathrm{nrn} 3313$

Cui, X., Jeter, C. B., Yang, D., Montague, P. R., and Eagleman, D. M. (2007). Vividness of mental imagery: individual variability can be measured objectively. Vision Res. 47, 474-478. doi: 10.1016/j.visres.2006.11.013

De Koning, B. B., and Van der Schoot, M. (2013). Becoming part of the story! refueling the interest in visualization strategies for reading comprehension. Educ. Psychol. Rev. 25, 261-287. doi: 10.1007/s10648-013-9222-6

DeNaeghel, J., Van Keer, H., Vansteenkiste, M., Haerens, L., and Aelterman, N. (2013). Enhancing Primary Students' Autonomous Reading Motivation: Impact of an SDT-Based Teacher Training. Paper Presented at the European Association for Research on Learning and Instruction (EARLI). Available at: http://hdl.handle.net/1854/LU-4247156

Dollinger, S. J., and Malmquist, D. (2009). Reliability and validity of single-item selfreports: with special relevance to college students' alcohol use, religiosity, study, and social life. J. Gen. Psychol. 136, 231-242. doi: 10.3200/GENP.136.3.231-242

Eccles, J. S., and Wigfield, A. (2002). Motivational beliefs, values, and goals. Annu. Rev. Psychol. 53, 109-132. doi: 10.1146/annurev.psych.53.100901.135153

Ferguson, P. D., and Fraser, B. J. (1998). Changes in learning environment during the transition from primary to secondary school. Learn. Environ. Res. 1, 369-383. doi: 10.1023/A:1009976529957

Gardner, L. L., Cummings, R. B., Dunham, R. B., and Pierce, J. L. (1998). Singleitem versus multiple-item measurement scales: an empirical comparison. Educ Psychol. Meas. 58, 898-915. doi: 10.1177/0013164498058006003

Gennari, S. P. (2012). Representing motion in language comprehension: lessons from neuroimaging. Lang. Linguist. Compass 6, 67-84. doi: 10.1002/ $\operatorname{lnc} 3.317$

Giedd, J. N. (2008). The teen brain: insights from neuroimaging. J. Adolesc. Health 42, 335-343. doi: 10.1016/j.jadohealth.2008.01.007

Gille, E., Loijens, C., Noijons, J., and Zwitser, R. (2010). Resultaten PISA2009 - Praktische Kennis en Vaardigheden Van 15-Jarigen; Nederlandse Uitkomsten Van Het Programme for International Student Assessment (PISA) op Het Gebied Van Leesvaardigheid, Wiskunde, en Natuurwetenschappen in Het Jaar 2009. [Results PISA-2009 - Practical Knowledge and Skills of 15-Year-Olds; Dutch PISA-Results on Reading, Mathematics, and Science in 2009]. Available at: http://www.cito.nl/nl/onderzoek\%20en\%20wetenschap/onderzoek/deelname_ onderzoek/pisa/resultaten.aspx

Glenberg, A. M. (2011). How Reading Comprehension is Embodied and Why that Matters. International Electronic Journal of Elementary Education,4,5-18. Available at: http://www.iejee.com/4_1_2011/IEJEE_4_1_October_2011.pdf

Green, M. C. (2004). Transportation into narrative worlds: the role of prior knowledge and perceived realism. Discourse Process. 38, 247-266. doi: $10.1207 /$ s15326950dp3802_5

Green, M. C., and Brock, T. C. (2002). "In the mind's eye: transportation-imagery model of narrative persuasion," in Narrative Impact: Social and Cognitive Foundations, eds M. C. Green, J. J. Strange, and T. C. Brock. (Mahwah, NJ: Lawrence Erlbaum Associates, Inc), 315-341.

Green, M. C., Kass, S., Carrey, J., Herzig, B., Feeney, R., and Sabini, S. (2008). Transportation across media: repeated exposure to print and film. Media Psychol. 11, 512-539. doi: 10.1080/15213260802492000

Guthrie, J. T., McRae, A., and Klauda, S. L. (2007). Contributions of conceptoriented reading instruction to knowledge about interventions for motivations in reading. Educ. Psychol. 42, 237-250. doi: 10.1080/004615207016 21087

Guthrie, J. T., Wigfield, A., and You, W. (2012). "Instructional contexts for engagement and achievement in reading," in Handbook of Research on Student Engagement, eds S. L. Christenson, A. L. Reschly, and C. Wylie. (New York: Springer), 601-634. doi: 10.1007/978-1-4614-2018-7-29

Havas, D. A., Glenberg, A. M., Gutowski, K. A., Lucarelli, M. J., and Davidson, R. J. (2010). Cosmetic use of botulinum toxin-A affects processing of emotional language. Psychol. Sci. 7, 895-900. doi: 10.1177/0956797610374742

Hibbing, A. N., and Rankin-Erickson, J. L. (2003). A picture is worth a thousand words: using visual images to improve comprehension for middle school struggling readers. Read. Teach. 56, 758-770.
Isaac, A. R., and Marks, D. F. (1994). Individual differences in mental imagery experience: developmental changes and specialization. Br. J. Psychol. 85, 479-500. doi: 10.1111/j.2044-8295.1994.tb02536.x

Jacobs, J. E., Lanza, S., Osgood, W. D., Eccles, J. S., and Wigfield, A. (2002). Changes in children's self-competence and values: gender and domain differences across grades one through twelve. Child Dev. 73, 509-527. doi: 10.1111/1467-8624. 00421

Klauda, S. L. (2009). The role of parents in adolescents' reading motivation and activity. Educ. Psychol. Rev. 21, 325-363. doi: 10.1007/s10648-0099112-0

Lenroot, R. K., and Giedd, J. N. (2010). Sex differences in the adolescent brain. Brain Cogn. 72, 46-55. doi: 10.1016/j.bandc.2009.10.008

Logan, S., and Johnston, R. (2009). Gender differences in reading ability and attitudes: examining where these differences lie. J. Res. Read. 32, 199-214. doi: 10.1111/j.1467-9817.2008.01389.x

Love, K., and Hamston, J. (2004). Committed and reluctant male teenage readers: beyond bedtime stories. J. Lit. Res. 36, 335-400. doi: 10.1207/s15548430jl r3603_4

Mar, R. A. (2004). The neuropsychology of narrative: story comprehension, story production, and their interrelation. Neuropsychologica 42, 1414-1434. doi: 10.1016/j.neuropsychologia.2003.12.016

Mar, R. A., and Oatley, K. (2008). The function of fiction is the abstraction and simulation of social experience. Perspect. Psychol. Sci. 3, 173-192. doi: 10.1111/j.1745-6924.2008.00073.x

Mar, R. A., Oatley, K., Hirsh, J., and Peterson, J. B. (2006). Bookworms versus nerds: exposure to fiction versus non-fiction, divergent associations with social ability, and the simulation of fictional social worlds. J. Res. Pers. 40, 694-712. doi: 10.1016/j.jrp.2005.08.002

Matlock, T. (2004). Fictive motion as cognitive stimulation. Mem. Cogn. 32, 13891400. doi: 10.3758/BF03206329

Ministry of Education, Culture and Science. (2006). Besluit Vaststelling Kerndoelen Onderbouw VO en Aanpassing Inrichtingsbesluit WVO [Decision Establishing Core Objectives for the Lower School in Secondary Education and Amending the Decision Iimplementing the Law on Secondary Education] (Kamerstuk WJZ/2006/24505(3805). Available at: http://www.rijksoverheid.nl/documenten-en-publicaties/kamerstukken/2006/06/ 16/besluit-vaststelling-kerndoelen-onderbouw-vo-en-aanpassing-inrichtingsbesl uit-wvo.html

Ministry of Education, Culture and Science. (2011). Kernciifers 2006-2010; Onderwijs, Cultuur en Wetenschap [Core numbers 2006-2010; Education, Culture and Science]. Available at: http://www.rijksoverheid.nl/ministeries/ocw/documentenen-publicaties/brochures/2011/05/12/kerncijfers-2006-2010.html

Mol, S. E., and Bus, A. G. (2011). To read or not to read: a meta-analysis of print exposure from infancy to early adulthood. Psychol. Bull. 137, 267-296. doi: $10.1037 / \mathrm{a} 0021890$

Morgan, P. L., and Fuchs, D. (2007). Is there a bidirectional relationship between children's reading skills and reading motivation? Except. Child. 73, 165-183. doi: $10.1177 / 001440290707300203$

Mullan, K. (2010). Families that read: a time-diary analysis of young people's and parents' reading. J. Res. Read. 33, 414-430. doi: 10.1111/j.1467-9817.2010. 01438.x

Oatley, K. (1999). Why fiction may be twice as true as fact: fiction as cognitive and emotional simulation. Rev. Gen. Psychol. 3, 101-117. doi: 10.1037//10892680.3.2.101

Oatley, K. (2011). Fiction and its study as gateways to the mind. Sci. Study Lit. 1, 153-164. doi: 10.1075/ssol.1.1.16oat

Oatley, K. (2012). The cognitive science of fiction. Wiley Interdiscip. Rev. Cogn. Sci. 3, 425-430. doi: 10.1002/wcs.1185

OECD. (2010). PISA 2009 Results: Learning to Learn: Student Engagement, Strategies and Practices, Vol. III. Pisa: OECD Publishing. doi: 10.1787/199 63777

Pedersen, S. (2005). Urban adolescents' out-of-school activity profiles: associations with youth, family, and school transition characteristics. Appl. Dev. Sci. 9, 107124. doi: 10.1207/s1532480xads0902_5

Reed, H., Ouwehand, C., Van der Elst, W., Boschloo, A., and Jolles, J. (2010). "Measures of school performance for use in educational neuropsychology," in Frontiers in Neuroscience Conference Abstract: EARLI SIG22 - Neuroscience and Education, Zürich. doi: 10.3389/conf.fnins.2010.11.00058 
Retelsdorf, J., Köller, O., and Möller, J. (2011). On the effects of motivation on reading performance growth in secondary school. Learn. Instr. 21, 550-559. doi: 10.1016/j.learninstruc.2010.11.001

Richardson, J. T. E. (1995). Gender differences in the vividness of visual imagery questionnaire: a meta-analysis. J. Ment. Imagery 19, 177-187.

Sadoski, M., and Paivio, A. (2001). Imagery and Text: A Dual Coding Theory of Reading and Writing. Mahwah, NJ: Lawrence Erlbaum Associates.

Schiefele, U., Schaffner, E., Möller, J., and Wigfield, A. (2012). Dimensions of reading motivation and their relation to reading behavior and competence. Read. Res. Q. 47, 427-463. doi: 10.1002/RRQ.030

Schram, D. H. (2007). Lezen in Het VMBO [Reading in the Pre-Vocational Track]. Amsterdam: Stichting Lezen.

Shaw, P., Greenstein, D., Lerch, J., Clasen, L., Lenroot, R., Gogtay, N., et al. (2006). Intellectual ability and cortical development in children and adolescents. Nature 440, 676-679. doi: 10.1038/nature04513

Souvignier, E., and Mokhlesgerami, J. (2006). Using self-regulation as a framework for implementing strategy instruction to foster reading comprehension. Learn. Instr. 16, 57-71. doi: 10.1016/j.learninstruc.2005.1 2.006

Speer, N. K., Reynolds, J. R., Swallow, K. M., and Zacks, J. M. (2009). Reading stories activates neural representations of visual and motor experiences. Psychol. Sci. 20 989-999. doi: 10.1111/j.1467-9280.2009.02397.x

Telford, L. (1999). A study of boys' reading. Early Child Dev. Care 149, 87-124. doi: 10.1080/0300443991490107

Tellegen, S., and Frankhuisen, J. (2002). Waarom is Lezen Plezierig? [Why is Reading Enjoyable?]. Delft: Eburon.

The Dutch Inspectorate of Education. (2012). De Staat Van Vet Onderwijs; Onderwijsverslag 2010-2011 [The Status of Education; Educational Report 2010-2011]. Utrecht: The Dutch Inspectorate of Education.
Wanous, J. P., Reichers, A. E., and Hudy, M. J. (1997). Overall job satisfaction: how good are single-item measures? J. Appl. Psychol. 82, 247-252. doi: 10.1037/00219010.82.2.247

Weibel, D., Wissmath, B., and Mast, F. W. (2011). Influence of mental imagery on spatial presence and enjoyment assessed in different types of media. Cyberpsychol. Behav. Soc. Netw. 14, 607-612. doi: 10.1089/cyber.2010.0287

Yao, B., Belin, P., and Scheepers, C. (2011). Silent reading of direct versus indirect speech activates voice-slective areas in the auditory cortex. J. Cogn. Neurosci. 23, 3146-3152. doi: 10.1162/jocn_a_00022

Yarkoni, T., Speer, N. K., and Zacks, J. M. (2008). Neural substrates of narrative comprehension and memory. Neuroimage 41, 1408-1425. doi: 10.1016/ j.neuroimage.2008.03.062

Conflict of Interest Statement: The authors declare that the research was conducted in the absence of any commercial or financial relationships that could be construed as a potential conflict of interest.

Received: 05 July 2014; accepted: 07 October 2014; published online: 27 October 2014. Citation: Mol SE and Jolles J (2014) Reading enjoyment amongst non-leisure readers can affect achievement in secondary school. Front. Psychol. 5:1214. doi: 10.3389/fpsyg.2014.01214

This article was submitted to Educational Psychology, a section of the journal Frontiers in Psychology.

Copyright (c) $2014 \mathrm{Mol}$ and Jolles. This is an open-access article distributed under the terms of the Creative Commons Attribution License (CC BY). The use, distribution or reproduction in other forums is permitted, provided the original author(s) or licensor are credited and that the original publication in this journal is cited, in accordance with accepted academic practice. No use, distribution or reproduction is permitted which does not comply with these terms. 